Gramáticas de la (¿post?) violencia:

identidades, guerras, cuerpos y fronteras

\title{
Deserving victimhood: kinship, emotions and morality in contemporary politics
}

Virginia Vecchioli ${ }^{1}$

' Universidade Federal de Santa Maria,

Programa de Pós-graduação em Ciências Sociais, Santa Maria/RS, Brasil

\begin{abstract}
This paper is about the place of family values, kinship relations and feelings of compassion for victims in national public space. Setting out from a description of various public affairs concerning the relatives of disappeared in Argentina, I show the key role played by blood ties and family values in forming a legitimate political representation. While the claim of blood ties with victims had been instituted as a legitimate form of political representation ever since the return to democracy, over the last decade or so sentiments towards victims have become incorporated into the State, enabling the latter to be imagined as a victim too. Here I explore diverse assessments of these affective dispositions, the critical place attributed to suffering in forging forms of governmentality, and the significant role played by the State in the unequal distribution of feelings of compassion.
\end{abstract}

Keywords: victims; humanitarianism; kinship; State; affects. 


\section{Merecendo a condição de vítima: parentesco, emoções e moralidade na política contemporânea}

\section{Resumo}

Este artigo trata sobre o lugar dos valores familiares, das relações de parentesco e dos sentimentos de compaixão para com as vítimas na política. Sob a base da descrição de vários affaires públicos relativos aos familiares de desaparecidos políticos na Argentina, apresento o lugar chave que ocupam os laços de sangue e os valores familiares na conformação de uma representação política legitima. Se a reivindicação dos laços de sangue com as vítimas constituiu uma forma legitima de representação política desde o início da democracia, a partir dos últimos quatorze anos os sentimentos para com as vítimas fizeram seu ingresso ao Estado, fazendo possível que ele seja imaginado também como uma vítima. Analiso o valor destas disposições afetivas, o lugar chave dado ao sofrimento das vítimas na criação de formas de governamentalidade e o papel significativo que tem o Estado na distribuição desigual destes sentimentos de compaixão.

Palavras-chave: vítimas; humanitarismo; parentesco; Estado; afetos.

\section{Merecer la condición de víctima: parentesco, emociones y moralidad en la política contemporanea}

\section{Resumen}

Este artículo trata sobre el valor de los valores familiares, las relaciones de parentesco y los sentimientos de compasión con las víctimas en la política contemporánea. Tomando como punto de partida el análisis de una serie de eventos públicos relacionados con los familiares de los desaparecidos en la Argentina, analizo el lugar central que ocupan los vínculos de sangre y los valores de la familia en la conformación de una representación política legítima. Mientras que la reivindicación de un vínculo de sangre con las víctimas se instituyó como una forma de representación política legítima desde el retorno a la democracia, a lo largo de la última década, los sentimientos de compasión hacia las víctimas hicieron su ingreso al Estado, haciendo posible que sea imaginado como una víctima. Analizo en este trabajo el valor de estas disposiciones afectivas, el lugar crítico que ocupa el sufrimiento de las víctimas en la creación de formas de governamentalidad y el papel significativo que tiene el Estado en la distribución desigual de sentimientos de compasión.

Palabras clave: víctimas; humanitarismo; parentesco; Estado; afectos. 


\title{
Deserving victimhood: kinship, emotions and morality in contemporary politics
}

\author{
Virginia Vecchioli
}

\section{Introduction}

We do not mourn mass murder unless we have already

identified with the victims, and this only happens

once in a while, when the symbols are aligned

Alexander, 2002:4

After thirty-six years of relentless searching, on August $5^{\text {th }}$ 2014, Estela Barnes de Carlotto, president of the Grandmothers of the Plaza de Mayo Association (Asociación Abuelas de Plaza de Mayo), ${ }^{1}$ finally found her own grandson, Ignacio, son of her daughter Laura, who had disappeared during the dictatorship and was killed after giving birth. ${ }^{2}$ While each appearance of the previous 113 grandchildren had also been marked by press conferences and the publication of news reports, this case broke with all the Association's previous routines and became an extraordinary event and a media sensation: Estela made the front pages of the country's leading national newspapers, Estela and Ignacio were pictured on the cover of a well-known current affairs magazine along with other 'famous' personalities of the year, ${ }^{3}$ and subsequently appeared on numerous television shows broadcast to large national audiences. Estela, accompanied by her grandson Ignacio Montoya Carlotto, was received by then president Cristina Fernández de Kirchner and by the head of the Catholic Church, Pope Francis. Just a few months later, the first books on the case were already being published (Seoane \& Caballero 2015; Folco 2015).

On the same day and at the same time, as the conference at which Ignacio was presented to the public, María Victoria Moyano Artigas, Recovered Grandchild 53, was taking part in a union protest when she was brutally arrested by security forces from the national gendarmerie. Attacked initially with pepper spray, her car window was smashed, the door wrenched open and she was dragged out of the car by force and hauled off to a police station with other union leaders and activists. Given the simultaneity of these events, the scant public attention devoted to María Victoria's arrest becomes particularly significant. No figures from the national government would mention the incident and the national press provided little coverage in contrast to the innumerable pages devoted to the appearance of Ignacio, Grandchild 144. These acts of repression by the State against a recovered granddaughter aroused neither feelings of compassion for her misfortune, nor moral indignation over the infringement of political rights under the rule of law.

\footnotetext{
Referred to hereafter as Grandmothers (Abuelas).

During the dictatorship, the State armed forces illegally appropriated an estimated 500 children born to disappeared women, or kidnapped along with their parents, and handed them over to other families to be raised under different identities. In most cases, these families belonged to the armed forces (Regueiro 2010). After the return to democracy, a 'grandparentage index' (índice de abuelidad) was developed to prove the genetic relationship between alternate generations, even in the absence of living parents.

3 They appeared on a cover photo alongside artists, show business celebrities and media people. See the magazine Revista Gente. No. 2577. December 2014.
} 
How can we explain this uneven distribution of compassion towards victims of State terrorism who objectively share the same condition? What processes allow some victims to acquire titles of nobility in Argentinean politics? Both grandchildren were born in clandestine camps, their parents had been disappeared and both had been raised under a fictitious identity by appropriator families. Yet, despite these similarities, they failed to elicit the same feelings of compassion or share the same public legitimacy.

This article is about the place of family values, kinship relations and feelings of compassion for victims in contemporary politics. It explores the unequal distribution of feelings of compassion towards victims, assuming that the contrast between public indifference over Victoria's arrest and the public concern and emotional outpouring over Ignacio's appearance provides an insight into the structure of moral feelings responsible for establishing frontiers and hierarchies within this universe of social relationships. As Sarti recognizes in her analysis of the social construction of the category of victim, paying attention to those left in the shadows enables us to comprehend this as a moral rather than legal process (Sarti 2011: 54). Following her suggestion, my intention here is to explore in depth the establishment of borders among social actors ostensibly sharing the same circumstances. I plan to analyse the social conditions that allow the recognition of 'good victims' and 'good families' as opposed to those who, subject to the same historical conditions, are deemed illegitimate victims - or at the very least 'bad' victims who deserve public indifference. As we shall see, these borders and hierarchies involve critical political issues linked to recent transformations in the relationship between the Argentine State and the human rights movement.

Setting out from this brief sketch and based on the description of various public episodes, I show the key role played by blood ties and family values in forming a legitimate representation of victims that allows them to participate in contemporary politics. This aim in mind, I focus on describing: a) the attributes that qualify human rights leadership in post-dictatorship politics; b) the qualities of grandchildren that enable them to be included within the boundaries of their biological families and, in the process, within the national community; and c) the recent transformation in the prominence of victims since the coming to power of Kirchnerism (2003-2015). ${ }^{4}$ While the claim of blood ties with victims was instituted as a form of legitimate political representation after 1983 and Argentina's return to democratic governance (Vecchioli 2005), over the last fourteen years sentiments concerning victims have been incorporated within the State itself, allowing the latter to be imagined as a family of victims too. Emotions and feelings about victims and their relatives have assumed a critical place in the State's integration. How then can we account for the significance of kinship categories for political action? What does the language of kinship ties express about the relations between the State and civil society?

This article converges with a recent literature that recognizes the increasing amount of space occupied by victims and humanitarian sentiments in contemporary politics and the role that compassion, sentiments and imagination play in shaping forms of governmentality (Alexander 2002; Fassin 2011; Sarti 2011). Its implications for the present case will be covered at length over the course of this article. To accomplish these aims, I draw on authors who link family, kinship and politics (Lenoir 2003; Das 1996; Anderson 1991; Bourdieu 2001) in order to understand the place of blood relations within the State. Following the inspiration of Veena Das (1996), who based his ethnography of Indian national society on diverse forms of public speeches, here I analyse discourse and imagery as signifying practices and performative acts that contain a series of moral imperatives and emotional and rhetorical resources. A common memory between victims and the State is established through the latter, while symbolic borders are instituted within this moral community. By engaging in a microscopic analysis of these performative acts, I reflect on broader issues linked to the political transformations in Argentina's post-dictatorship era.

4 'Kirchnerism' is the name given to the political current that arose around the figures of Nestor and Cristina Kirchner within Peronism, a national political party. Nestor was president during the period 2003-2008 and Cristina between the years 2008-2015. 
Taking affects to be the very substance of politics (Stoler 2007) rather than an epiphenomenon (Laszczkowski \& Reeves 2015), this article inscribes itself in current debates on the place of compassion towards victims in modelling contemporary politics. As Hirschman suggests, "sentiment's history is an inspired way to trace the changing form and content of what constitutes the subject and terrain of politics" (Hirschman 1977: 16). Among the vast literature produced on the topic, Jenkins (1991) and Stoler (2007) are especially useful to the understanding of our case since they analyse how States "culturally standardize the organization of feeling" (Jenkins 1991: 140) and the political consequences produced by "technologies of rule" based on sentiments (Stoler 2007). Setting out from these premises and recognizing that affections are the moralizing self-presentation of State (Stoler 2007), I explore the diverse assessments of these affective dispositions, the critical place assigned to the suffering of the victims of State terrorism, and the significant role played by the State in the distribution of sensibilities surrounding victims and their relatives.

The academic literature on the Argentinean dictatorship encompasses many crucial issues such as the reconstruction of the repressive modalities used by the Armed Forces (Calveiro 2008), the emergence of the human rights movements (Catela 2001), the development of transitional justice mechanisms (Teitel 2002) and the social construction of emblematic memories (Crenzel 2011). In this article I shall dialogue with this well-established literature by looking to move beyond such canonical topics and analyse the prominence of the relatives of the victims in the ways of doing and imagining politics in the post-dictatorship period. By adopting such an approach, I seek to fill a gap in the existing literature, placing victims and their relatives at the heart of the State and shedding new light on the ways in which the human rights cause, its protagonists and the sentiments and values associated with them are intertwined with State practices and shape current politics.

My analysis is based on a comprehensive survey of public documentary sources on the restitution of children of the disappeared produced between 2004 and 2017, as well as earlier ethnographic field research on a number of different State agencies responsible for dealing with the relatives of victims. ${ }^{5}$

\section{Blood ties in the political space}

The appearance of Grandchild 114 proved to be an extraordinary event: a unique occurrence that attracted the involvement of many people with no direct connection to the case, turning into an emotional drama shared by wider Argentinean society. This situation became evident at the press conference, a routine event held to celebrate the appearance of each new grandchild. On this occasion, though, the Grandmothers head office was too small to accommodate the large crowd that turned up spontaneously to celebrate the encounter. Instead, they accompanied the announcement from the streets, cheering, singing and blowing cars horns. After the conference, Estela came out onto the balcony to thank those expressing their solidarity outside. Over the following days, a poster made by the Grandmothers appeared celebrating the event in Buenos Aires's streets: "114 recovered grandchildren. Each of them a prize of peace and love".

Newspaper reports emphasized the collective emotion that led to the recovery of Ignacio's identity, who immediately became "everyone's grandson" and "a whole symbol" of the unwavering struggle of the Grandmothers and of the value of love and caring expressed by their endless searching. Media reports

\footnotetext{
5 Public discourses were compiled from newspapers, magazines, books, television shows, brochures and the internet, among other sources. Although the present work focuses on public documents, informal conversations with relatives of the victims of State terrorism - supported by almost 20 years of ethnographic research - also allowed me to identify references to the unequal nobility among children of the disappeared. The same applies to the unequal authority of the relatives of victims compared to activists from human rights movements who are not themselves victims, as I have analysed in a previous work (Vecchioli 2005)

6 The poster can be seen on-line via the La Nación newspaper https://www.lanacion.com.ar/1716162-el-afiche-que-celebra-la-aparicion-del-nieto-de-estelade-carlotto.Accessed on August 6 ${ }^{\text {th }}, 2014$.
} 
emphasized the feelings stirred by the event: surprise, excitement, joy, affection. These sentiments were extended beyond those directly involved as soon as Ignacio was considered "an exciting story for everyone." Ignacio's appearance was celebrated not just as a victory for the human rights associations but as a collective achievement, a cause for national celebration: "It is a triumph for all Argentineans"; "All the people of this country are joyful about this moment and share their happiness with us".? The feeling of joy was compared to winning a football world cup, a national passion. Not for nothing Ignacio was baptized "the Messi of the grandchildren" in reference to Argentine soccer player and world superstar Lionel Messi.

Academic experts were also unanimous in highlighting this same emotional dimension: "Why had such a unique case [...] touched millions of people as though it were someone in our own family? Who did not share her [Estela's] joy?” (Ludueña 2014: 6). "A 'physical happiness' mysteriously revealed to thousands of people on receiving the news until precipitating a few hours later into a collective emotion" (Taitan 2004: 15). In evaluating the event, distinctions between the victims were emphasized: "tears welled up easily, the result of feelings of empathy stirred by the heart-breaking story, but also as a result of the long search that had finally resulted in this moving encounter. He is a grandson like the others recovered and the others still missing, but a grandson whose grandmother is a symbol. And so, he is not just one more grandchild" (Crenzel 2014).

Events that followed Ignacio's recovery show the leading role played by the families of victims in public space. The press conference at which Estela announced Ignacio's appearance was transformed into a fullblown civic ceremony through which the sacred value of blood ties was reaffirmed as a central element in political life, in the sense that Durkheim attributes to rites as moments when "it is possible to discern [...] the emotional mobilizations that it displays, in which are invoked norms, values, representations, beliefs [...] that define this group" (Durkheim 2012: 233). This is an outcome not only of the disappearance of thousands of people during the last military dictatorship, but also of the powerful confluence between the moral values expressed in family bonds and the collective activism sustained over a forty-year period. Ever since its emergence, the human rights movement has been distinguished by the fact that a large proportion of its activists are publicly identified by their claim of a blood tie with victims. ${ }^{8}$ A simple review of the names given to the different groups making up the human rights movement reveals the foundation of a political community that publicly expresses its self-recognition through the language of kinship: Relatives of the Detained and Disappeared for Political Reasons (1976), Mothers of the Plaza de Mayo (1977) and Grandmothers of the Plaza de Mayo (1977).

Victim activism creates a community of peers through the extension of individual ties of consanguinity between the victim and their families to all those taking part in this struggle, as reflected in the testimony of one mother: "the fact of having someone who has disappeared, just that alone, leads to the establishment of a sisterhood among us" (Mellibovsky 1990: 93). In the Grandmothers organization, recovered grandchildren have replaced and continued the work of deceased grandmothers (Bublik 2013: 151), enabling the creation of a community of peers based on a non-transferable bond that imbues this shared quality to all relations within this imagined community (Das 1996; Anderson 1991). ${ }^{9}$ Among this group, maternity and filiation are the primary and fundamental sources of human rights activism. As claimed by both Mothers and Grandmothers, they were willing to do anything to find their children and grandchildren and continue

\footnotetext{
Claudia Carlotto "Estamos Felices," Página/12 Newspaper, August $7^{\text {th }}$, 2014. Available at http://www.pagina12.com.ar/diario/elpais/1-252432-2014-08-07.html. Accessed on March 12 ${ }^{\text {th }}, 2015$.

8 Under democracy, this principle remained in force after the classic channels of mediation between civil society and State had been restored, as evident in the creation of Children for Identity and Justice against Oblivion and Silence (HIJOS 1995) and Siblings of Disappeared for Truth and Justice (Herman@s, 2003).

9 The case of the Centre for Legal and Social Studies (CELS 1979) exemplify the socially constructed nature of the bond of familiarity: it was founded by a group of relatives of disappeared persons who made law their principle of public recognition.
} 
to do so because, from their viewpoint, their struggle cannot be broken by any force because it arises from the "maternal instinct" (Filc 1997; Vecchioli 2005). From these primordial maternal bonds derive the strength, courage and resistance demonstrated throughout forty years of activism.

Public discourses that arose from the appearance of the grandson of Estela, the main leader of Grandmothers, reveal the effectiveness of this basic principle as a fundamental element in constituting this political community, its legitimacy and the level of sentimentalization of public space. They expose the centrality of family values and kinship in the shaping of political communities and the humanitarian sentiments mobilized in the production of collective support. Political practices - which claimed the particularity of blood in the creation of exclusive moral communities - acquired a national appeal through emotions and humanitarian sentiments towards victims and their relatives, both recognized as national symbols.

\section{The grandmother, an example of love}

Ignacio's appearance cast a spotlight on the profile and trajectory of a mother and grandmother with whom many Argentineans could readily identify. Although Estela is widely known as the leader of one of the most prestigious human rights associations, the qualities emphasized in the days that immediately followed her encounter with Ignacio primarily focused on her role as a mother and grandmother. She was described innumerable times as an "everyday mother" and an "example of love." cultivate this family profile by recounting her personal history repeatedly, sticking to a formulaic narrative that evoked the prototypical history of an urban middle-class family mother: a native of Buenos Aires, born 86 years ago into a Catholic home of immigrants, married to her first and only boyfriend, graduated from an industrial college and owner of a local painting business. Estela was a teacher and director of a public school on the outskirts of the city of La Plata. With no vocation for politics, her life was devoted to raising her four children, her husband and the school.

Among the stock of anecdotes, preeminence was given to her delight in cooking and sewing, her family nickname, Nata, the Sunday family meal surrounded by children and grandchildren, her coquettish air, her simplicity, and her austere life (Seoane \& Caballero, 2015:40). These qualities were further enhanced by the publicity given to photographs from her family album, showing her dressed in white on the day of her wedding, holidaying on the beach with her small children, or wearing her teacher's gown in her workplace. This account was repeated incessantly in radio, television and printed reports, and moreover was a reiteration in exactly the same terms, using the same photos and anecdotes, of reports and news items published over previous years by different press outlets, revealing the construction of a stereotyped form of presenting her public biography.

These qualities, applicable to any urban middle-class family mother, are insufficient to engender the kind of collective outpouring of compassion expressed in the days following Ignacio's appearance. These very same qualities were shared by the paternal grandmother, Hortensia Ardura de Montoya, mother of the disappeared Oscar, Ignacio's father. Like Estela, she was a teacher and director of a public school and devoted herself to raising her family. But unlike the maternal grandmother, Hortensia received little public attention and few newspaper reports were dedicated to portraying the paternal side of the family.

This difference reveals a hierarchy founded not on biological relationships with the victims but on the possibility of reconverting personal suffering into political engagement. Hortensia lives in a small Patagonian town more than $1500 \mathrm{~km}$ from Buenos Aires. Even though she asked for the disappeared son,

10 "Una búsqueda que comenzó hace 36 años" Página/12 newspaper. August $6^{\text {th }}$, 2014, Accessed on August 6 $6^{\text {th }}$, 2014. http://www.pagina12.com.ar/diario/ elpais/1-252357-2014-08-o6.html 
Hortensia had never engaged in human rights activism and remained in a distant small village. Estela, by contrast, had started to take part in what was then called the Association of Argentinean Grandmothers with Disappeared Grandchildren (Abuelas Argentinas con nietitos desaparecidos) immediately after the disappearance of her daughter, a political engagement that she would maintain over a span of forty years, chairing the association since 1989. These contrasting cases show that the 'Grandmother' condition is not acquired automatically as a result of a biological bond with an appropriated grandchild but from engagement in activism. The existence of relatives who do not belong to human rights associations indicates that being the bearer of this bond of maximal proximity to the victims is a property socially constructed and objectified by a group of people who identify themselves in the public space through the use of kinship categories.

Human rights activism by itself is not enough to occupy the highest positions in the hierarchy of prestige. In the days that followed the encounter with Ignacio, other qualities were highlighted to distinguish Estela from other human rights leaders, qualified by contrast, as violent and fanatic. Estela was famed for her 'serenity,' 'strength,' 'bravery' and 'admirable solidarity' (Baltazar Garzón apud Folco 2015: 10), her composure in the face of extreme situations, combined with her peaceful, serene and soft tone, accompanied with calm 'maternal' gestures. But while Estela was portrayed in every media report as a person harbouring no feelings of rancour or vengeance, these very same qualities were attributed to Hebe de Bonafini, also a mother of disappeared and the leader of Mothers of the Plaza de Mayo Association (Asociación Madres de Plaza de Mayo) since 1986. Estela too always distinguishes herself from Bonafini in every public intervention, appealing not to rational arguments but to the language of feelings:

My language is not aggressive, it is conciliatory, it opens doors, it does not close them [...] as a mother, I respect her: she is a mother who suffers and searches, but her form of acting, her methodology, her objectives are not those of the Grandmothers [...] As an institution, [we are] characterized by not holding onto resentments or hate, nor payback or vengeance [...] We don't share anything in common, we don't agree with the forms [they use] nor with various remarks that are contrary to our objective [...] she said that 'there's no need to search for the grandchildren because they're already contaminated, they're beyond saving'."

Far from wishing to further cement this distinction by assessing the accuracy of each description, or by reducing these differences to basic psychological traits, my intention here is to make them sociologically comprehensible and, in so doing, reveal the moral economy that organizes human rights activism, allowing us to understand the collective emotions aroused by some of their leaders. In other words, the qualities performed by Estela explain her consecration at the top of a moral hierarchy.

The expressions described here show the emotional logic that connects the moral status of this kind of activism, one based on family values and biological ties, to the way in which sentiments are expressed in political practice. The sentiments revealed in demanding recognition for victims informs the legitimacy of this political practice. Hatred, vengeance, resentment and violence are deemed to be illegitimate properties for engagement in human rights. Instead, love, serenity, solidarity and affection - all of which Estela encapsulated - locate this engagement to idealistic political expectations concerning our collective life. Relatives thus became significant players in political life so long as they conform to these moral expectations. Contrasting personal characteristics render visible the tensions within this universe, as well as the pretentions to demarcate the symbolic boundaries within the community of victims. As Stoler points out, moral condition is crucial as it serves as the basis of citizenship (Stoler 2007:8).

11 Interview by J. Fontevecchia with Estela. August $10^{\text {th }}$, 2014. Available at

http://www.perfil.com/sociedad/Bonafini-dijo-que-a-los-nietos-no-hay-que-buscarlos-porque-ya-estan-contaminados-20140809-oog3.html Accessed on August 10 ${ }^{\text {th }}, 2014$. 


\section{Genetic imprints as moral forces}

As the days passed, the news reports on the encounter between Estela and Ignacio continued to draw public attention, not just because of the grandmother's fame, but also because of the qualities of her newlyfound grandson transmitted through the media: in the account that circulated publicly, Ignacio was born in 1978 while his mother, Laura Carlotto, was being held captive in a clandestine detention centre. A few hours after his birth, the baby was illegally handed over for adoption and raised in a rural area (Olavarría), just some $350 \mathrm{~km}$ from Buenos Aires, by a peasant couple unaware of Ignacio's true origin. When Ignacio learned of his adopted status in 2014, he approached the Grandmothers with his suspicion that he might be a disappeared child.

Public surprise not only stemmed from the relatively short geographic distance that had separated grandson and grandmother. There were also an enormous number of coincidences between Ignacio and his biological family that were repeatedly mentioned in public: for the grandmother Hortensia: "He is just like his father, he is indisputably the son of my son. When I looked at him, I saw my son, because he is a carbon copy". ${ }^{12}$ In the view of his maternal aunt, Claudia, Guido bore no physical resemblance to Laura. According to her, "Ignacio is a carbon copy of his father [...] On the other hand, he has a sense of humour very similar to our own and that reminds me of my sister". ${ }^{13}$ In the words of the grandson himself, "I saw the photos and he looks a lot like an older me. It was astounding". ${ }^{14}$

Photo 1: Press conference at Grandmothers Association

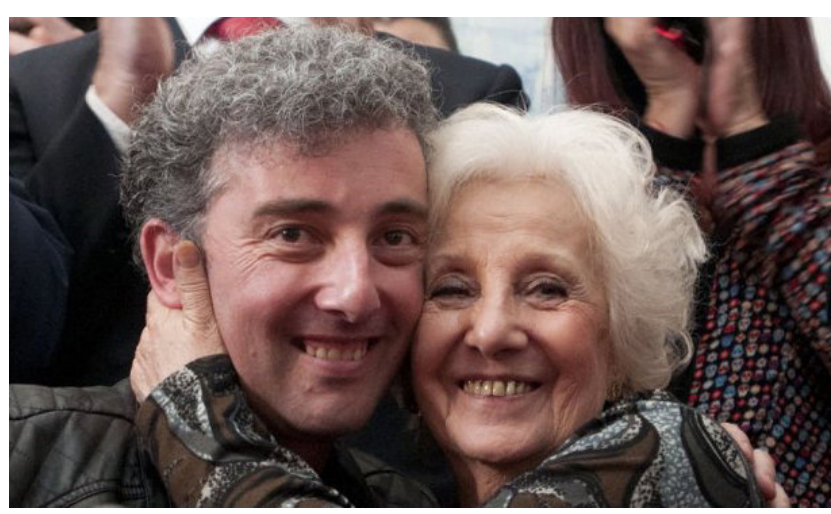

Source: La Nación newspaper

These similarities are not limited to the biological. In a happy coincidence with his father, Oscar, Ignacio is a fan of River Plate Football Club and a musician too - in fact a composer and the director of the municipal school of music. The grandson's own declarations emphasize the importance of this resemblance, interpreted as a product of genetic imprinting: "I'm a musician just like my father and paternal grandfather were, and a speaker just like my mother was". ${ }^{15}$ The bond with his biological family gave him an insight into his own gift for music: "The most astonishing thing is that I couldn't explain

\footnotetext{
12 H. Ardura. La Nación newspaper August 6 ${ }^{\text {th }}$, 2014. Available at http://www.lanacion.com.ar/1716158-hablo-la-otra-abuela-de-guido-y-lloro-por-laaparicion-de-su-nieto Accessed on August $6^{\text {th }} 2014$.

13 Claudia Carlotto "Estamos Felices" (op. cit.).

4 Ignacio Carlotto "El nieto de Carlotto exhibió su felicidad" La Nación newspaper. August $9^{\text {th }}$, 2014. Available at http://www.lanacion.com.ar/1717109-elnieto-de-carlotto-exhibio-su-felicidad-en-una-conferencia-cargada-de-emocion. Accessed on March $12^{\text {th }}, 2015$.

15 "Soy muy parecido a mi papá, verme en las fotos es algo que me golpea." Infojus Noticias. Available at

http://www.infojusnoticias.gov.ar/nacionales/soy-muy-parecido-a-mi-papa-verme-en-la-foto-es-algo-que-golpea-5473.html. Accessed on March $12^{\text {th }}$, 2015.
} 
where my musical vocation had come from" ${ }^{16}$ since the education he had received "had led me to something else" (he had trained as a master builder). In recovering his identity, blood was a central explanatory key: "there perhaps resides one of the most important answers". ${ }^{17}$

That question had always been left unanswered, like an outstanding debt: why did you become a professional musician? if you think about where I came from [...] This contradiction always jarred for me: I was raised in the rural world, yet I took a path so peculiar and foreign to that environment - not just my pursuit of music, but jazz in particular, living in a quest for the new, some kind of avant-garde, a spirit of constant searching that I could never explain". ${ }^{18}$

More surprising still, Ignacio was an ardent supporter of the human rights movement. In fact, he had composed a song 'To the Memory,' participated in 'Musicians for Identity,' a series of musical shows organized by Grandmothers four years earlier and celebrated the appearance of Grandchild 106 on his twitter account two years earlier. In his own words, what struck him was not just the physical resemblance but:

...the calls to do things that there was no reason for me to do: like being a musician, or playing every Memory Day and not knowing why - I'm not an activist or anything of the type - or writing 'To the Memory' and feeling it was a big part of who I am (op.cit.).

The overlaps between the histories of Ignacio and his disappeared parents allowed these actors to determine that they belong to the same family since "there are a lot of coincidences, intangible things that are obviously genetic in nature". ${ }^{19}$ In the narrative describing the recovery of Grandchild 114, the biographical data is presented in a form that highlights the irrefutable existence of 'a genetic memory', ${ }^{20}$ an interpretation that prevailed not only in the media and among social and political leaders, but also in expert analyses, as María Eugenia Ludueña alludes when she asks: "Just how influential are the imperturbable contents of our genes? What had Laura said/transmitted to him as she felt the baby growing and gently kicking in her belly?" (Ludueña 2014).

It is worth emphasizing that this focus on the strength of blood ties is not unique to this particular case. The same also appears as a recurring element in many of the restitutions. Ten years earlier, the grandchild Juan Cabandié had remarked:

...the dictatorship's sinister plan was unable to erase any record of the memory transmitted through my veins [...] The fifteen days during which my mother breastfed and named me were sufficient for me to tell my friends - before I knew who my family was, before I knew my history - that I wanted to call myself Juan, just as my mother had called me during imprisonment in ESMA [a former clandestine detention camp]" ${ }^{21}$

As in the case of Ignacio, filiation and blood appear as life-shaping elements that help explain the person's own biographical trajectory and, in this case, his vocation for political activism:

\footnotetext{
16 "Soy muy parecido a mi papá" (op.cit.).

17 "Soy muy parecido a mi papá" (op.cit.).

18 “Cuando Ignacio conoció a Guido.” Radar. 28/og/2014. Available at http://www.pagina12.com.ar/diario/suplementos/radar/9-10052-2014-10-04.html. Accessed on March $12^{\text {th }}, 2015$.

19 "Soy muy parecido a mi papá" (op.cit).

20 Ignacio Guido Carlotto, "Conferencia de prensa." Telam Agencia de Noticias. Available at

http://www.telam.com.ar/notas/201408/73924-el-nieto-restituido-de-estela-de-carlotto-dara-una-conferencia-de-prensa.html Accessed on April $5^{\text {th }}$, 2015.

21 Juan Cabandié 2004. Full speech available at http://www.abuelas.org.ar/discursos/do2.htm. Accessed on April $5^{\text {th }}, 2015$.
} 
I couldn't find any explanation [...] I thought differently to him [his abductor]. Why do I go on protests [...])? I wondered why I dedicated eight years of my life every Saturday to visiting a poor village or the homes of orphaned children to provide recreational activities. This left me wondering. Given the context in which I was raised, how did I end up doing that? Where did I get it all from? It was inside me [...] it's in my blood.

The testimonies cited above, which extol the similarity between the experiences of parents and children, express precisely a notion of the legitimate family, conceived as "a mode of group belonging founded on a community of shared condition, habitation and blood; in sum, a homogenous grouping whose internal cohesion is based on the 'similitude' of the actors who form part of it" (Lenoir 2003: 19).

Blood ties and filiation are represented as the legitimate bonds par excellence, evoking a worldview that transcends political and social positions, as well as any objective differences that may exist among the recovered children. Deployed by social movements, the State and the victims themselves, these narratives are structured around consecrated values and representations of the family, linked to the rhetoric of blood, origins, truth and genetics (Gatti 2011). Biological ideas concerning kinship imprint public narratives: "the blood circulating through their veins" is imposed as a principle that not only accounts for biological ties but also functions as a means to interpret destinies, career paths and personal preferences. This is the quality highlighted in the narrative shaping Ignacio's restitution.

\section{The recovered grandson, a good boy without resentment}

The transformation of Ignacio's recovery into a collective celebration was also achieved by combining Estela's qualities with another key ingredient: the moral qualities of the grandson. His relatives described him as "a good boy, someone they had raised well," "a healthy boy." According to Estela "he was raised in the rural world by a good family to whom he was delivered in good faith, without them being aware of his origin. They too had been victims of a 'deceit." ${ }^{22}$ In Ignacio's account: "If there is love, as there was in my childhood, and love as there was in the search [for me], it's easier." ${ }^{23}$ These warm, loving feelings extend to his own past in a perfect match with his grandmother's qualities: "I have no resentment, I feel highly privileged, perhaps uniquely so, because until a few months ago I had a phenomenal life [...] for me it is a moment of joy". ${ }^{24}$

This set of adjectives - "good child, good family" - positively qualify the history of the grandmothers' struggle, the genetic memory that circulates through grandchildren's veins and makes explicit the idea of the family as a key space of moral education: some grandchildren were raised by "good families" unconnected to the dictatorship and their restitution is a cause of celebration. While DNA tests provide the genetic evidence that enables the grandchildren to be returned to their biological families, it is their behaviour in response to the DNA findings that provides the proof needed for them to be returned to the warm embrace of their families, conceived now as a moral space. It becomes clear how, in the cosmology of the victims, concepts of the family as an institution founded on biological ties coexist with ideas of the family as a moral space. The conditions surrounding Ignacio's restitution evince the moral qualities of the families involved and their capacity to elicit strong feelings of empathy, emotion and redemption. The transformation of Ignacio's restitution into a collective celebration was made possible by the fact that both grandmother and grandson exemplified consecrated notions of family and victimhood.

\footnotetext{
22 Carlotto. "Estela de Carlotto recuperó a su nieto después de 36 años de búsqueda." La Nación newspaper. August $6^{\text {th }}$, 2014. Accessed on August $6^{\text {th }}$, 2014. Available at http://www.lanacion.com.ar/1716127-estela-de-carlotto-encontro-a-su-nieto-despues-de-36-anos-de-busqueda

23 Interview with Ignacio in El Popular newspaper. August $17^{\text {th }}, 2014$. Available at

http://www.elpopular.com.ar/eimpresa/194380/hablo-ignacio-guido-hurban-estoy-conmocionado-todavia accessed on August $17^{\text {th }}$, 2014.

24 “Soy muy parecido a mi papá” (op.cit.).
} 
All these categories and uses of language need to be understood in the context of the efforts made by other abducted grandchildren to prevent their identity from being recovered, to avoid becoming linked to their biological families or, at the very least, to minimize its symbolic effects, given that they still consider their appropriators to be their real parents. These conflicts include refusals to take DNA tests or to use the name of their biological family, leading in some cases to court litigations. The compulsory nature of the DNA test used to prove filiation has become controversial from the viewpoint of some kidnapped grandchildren since the knowledge of their true biological identity entails a) the immediate detention of their abductors for their responsibility in the crime of identity suppression, and b) the restitution of their original family names.

In this context, the words of Claudia, Ignacio's uncle, help explain the risks involved in any restitution: "the people who raised Ignacio had nothing to do with the repression [...] I was really worried [...] he had been raised by some shitty military type who would have filled his head with rubbish." ${ }_{25}$ This risk was identified by Estela too: "Each case of restitution has its own particularity [...] [it depends on] the child's response. When they come of their own volition it is fine, but when they don't, it usually turns out badly. In other words, it's very nuanced." ${ }^{26}$ This nuance was likewise recognized and emphasized by Argentina's president at the time, Cristina Kirchner: "Estela was lucky. Imagine if her grandson had been raised with hatred". ${ }^{27}$ Ignacio himself stated the same when he emphasized: "My upbringing was fantastic, raised by a couple who showered me with love [...] I had an extraordinarily happy life and to this happy and extraordinary life was added the marvel of being part of this history". ${ }^{28}$

Among academic experts, Ignacio's perceived qualities were emphasized and interpreted as an act of "double justice": Carlotto had found her grandson and "the grandson is this one" - that is to say, a grandson whose moral qualities corresponded to the values that distinguished his biological family:

This doesn't mean that had her recovered grandchild (like so many others) been someone bearing the indelible marks of violent abduction, or possessing ideologies and ways of life closer to those of the military, the encounter would have been impossible and his appearance less celebrated. But, finding Ignacio and discovering that he was filled 'with the truth that touches him,' wanting to trace his filial roots to his missing parents [...] more than resentment [...] it calms and cherishes" (Abdo Férez 2014).

The presence of "indelible marks of appropriation" and the upbringing in a family of perpetrators seem to converge on the paradigmatic case of Eva Donda, daughter of disappeared parents, raised under a false identity by her own paternal uncle, Adolfo Donda, a navy lieutenant and one of the principal perpetrators of human rights abuses at ESMA, a former clandestine detention centre. As in the cases of Ignacio and Juan, Eva's mother was disappeared after giving birth. Eva's father was Adolfo Donda's brother. He too disappeared. Taken away by her uncle and raised as his own daughter, Eva refused to carry out the DNA test voluntarily, ${ }^{29}$ still defends her abductor, in prison since 2006, and participates actively in the Association of Relatives and Friends of Victims of Terrorism in Argentina (Asociación de víctimas y familiars de víctimas del

\footnotetext{
25 Claudia Carlotto. "sos el nieto de Estela, sos mi sobrino" Página/12 newspaper. August $6^{\text {th }}$, 2014. Available at http://www.pagina12.com.ar/diario/elpais/1252353-2014-08-06.html. Accessed on August 6" ${ }^{\text {th }}$ 2014.

26 Interview with Estela de Carlotto in Página/12 newspaper. August $6^{\text {th }}, 2014$. Available at

http://www.pagina12.com.ar/diario/elpais/1-252359-2014-08-o6.html. Accessed on August 6 ${ }^{\text {th }}$, 2014.

27 “Historia de un encuentro íntimo." Página/12 newspaper. August 10 ${ }^{\text {th }}, 2014$, accessed on August $10^{\text {th }}, 2014$ Available at http://www.pagina12.com.ar/diario/ elpais/1-252672-2014-08-10.html

28 Ignacio Carlotto "Es maravilloso lo que estoy viviendo." Available at Agencia Telam. August 8 8 $^{\text {th }}, 2014$.

http://www.telam.com.ar/notas/201408/73924-el-nieto-restituido-de-estela-de-carlotto-dara-una-conferencia-de-prensa.html Accessed on August ${ }^{\text {th }}$, 2014. 
terrorismo en Argentina). This association campaigns for the end of trials for crimes against humanity and proposes a national reconciliation policy. According to Eva, her feelings of filial love for her abductor justify her current status as a 'victim.' Hence, she asserts:

...all of us are victims [...] my [biological] parents also did violent things. Today they would be imprisoned for terrorist acts [...] I wish for my uncle to be released. He's my paternal figure; he's my children's grandfather (Arenes \& Pikielny 2016: 48-52).

In other cases, complaints have focused on the use of the biological family name. This refusal was settled judicially in another paradigmatic case: Hilario Bacca, born in ESMA and identified by a DNA test as Federico Canola Pereyra, Grandson 95. Defining himself as a "son of the heart" of his abductors, he obtained his identity as a result of a compulsory DNA test carried out after legal intervention, which involved a raid on the family's home and the subsequent trial and conviction of his abductors. According to Hilario, after the intervention of the Grandmothers association, "the martyrdom of my life began": he was transformed into "a victim" for the courts, "a number" for Grandmothers and a "war trophy" for the people. Through an unexpected use of the category 'disappeared,' he accused courts of making him 'disappear' and denounced:

Prosecutors and Grandmothers believe that every time I'm named as Hilario Bacca a crime is committed [...] I feel that I'm being persecuted and [subject] to the same kind of [abusive] procedures that Liliana and Eduardo [his biological parents] experienced during the dictatorship. ${ }^{30}$

After nine years of legal disputes the courts allowed him to continue using the name given by his adoptive parents. Grandmothers refused the judicial decision because it: "violates the rights of the Cagnola and Pereyra families and constitutes an affront to the memory of his biological parents." For the association, it amounted to "a legalization of the dispossession that [...] their families suffered at the hands of State terrorism". " Estela's own grandson adopted the surnames of his biological family but continues to use the first name Ignacio given to him by his foster parents, refusing to register as Guido, the name given at birth by his mother before she was assassinated. According to Estela, this attitude "hurts me because the whole world searched for him as Guido. His mother gave him the name in memory of her father, Guido, my husband". ${ }^{22}$

From the viewpoint of the biological families of the grandchildren, the bad families force them to remain 'captives,' the 'slaves' of their abductors, even after their true biological identity has been confirmed. ${ }^{33}$ This is because being brought up among perpetrators leaves imprints: the love that they feel for the people who raised them. These grandchildren remain morally excluded from the community of legitimate victims until they accept the truth of their identity. Only then will they experience 'freedom' (Capiello 2014). It is this context that enables us to comprehend the semantic field in which the story of Ignacio's successful and miraculous recovery is narrated, including the incorporation into his biological family and into a nation that, conceived through blood ties and family values, celebrates his restitution.

As Fonseca has analysed among children with Hansen's disease, the DNA exam is conceived as "valid proof" within a system of concrete technologies that mediate what people know and feel. Photos, names, tastes and so on co-produce ways of reckoning personal identity and family ties (Fonseca 2015: 80). In the

\footnotetext{
30 "El nieto 95 denuncia desprotección del Estado y lucha por llevar el nombre que tuvo por 37 años." In Perfil newspaper http://www.perfil.com/sociedad/ El-nieto-95-denuncia-desproteccion-del-Estado-y-lucha-por-llevar-el-nombre-que-tuvo-por-37-anos--20151118-ooo8.html, Accessed on November 20 ${ }^{\text {th }}$, 2015. 31 Op.cit.

32 “Abuelas sobre el caso Bacca: Constituye una afrenta a su memoria." In Perfil newspaper, January $7^{\text {th }}$, 2017. Accessed on January $7^{\text {th }}$, 2017. Available at http://www.perfil.com/politica/abuelas-sobre-el-pedido-del-nieto-95-constituye-una-afrenta-a-su-memoria.phtml.

33 On the tensions between the relatives of victims, the bureaucratic and judicial logics and the 'legal battles' over the restitution of the victim's identity, see Regueiro 2010.
} 
cases described here, acquiring the status of a legitimate victim as a grandchild of someone disappeared depends on displaying the required proofs: not just the DNA test, but the cultivation of moral and political virtues (Fassin 2011).

\section{The state as a relative of victims}

The public staging of the restitution of Ignacio's identity was also a radical novelty in terms of the place that relatives and the State could legitimately occupy within Argentina's national political space. Ignacio's restitution was enacted as a family affair that included the State itself, since blood ties were extended to its most important representatives, testifying to the profound changes occurring within the human rights movement since the arrival of Kirchnerism to power (2003).

Since the returned to democracy (1983), all the devices developed by the State to manage the suffering of victims have demonstrated a) recognition of its responsibility for past human rights violations, as well as b) the legitimacy granted under democracy to the demands of relatives of the disappeared. State policies have covered a wide spectrum of actions, ranging from the creation of a truth commission (CONADEP 1983) to a civil criminal trial against the perpetrators of State terrorism (1985), the creation of a National Genetic Database (1987), a National Human Rights Secretariat (1991) and a National Commission for the Right to Identity (Conadi 1992), along with the adoption of international treaties in defence of human rights as part of domestic law (1994), among many other actions (Sutton 2015). In this process, the State has insisted on the need to specify the criteria used to identify those subjects wishing to be considered beneficiaries of these different policies, the victims. Since the beginning, the official category of victim was inseparably linked to recognition of another specific group: their relatives. For the state, therefore, a disappeared person is someone who "...in the vast majority of cases was ripped alive from the bosom of his family, kidnapped from his own home..." (Law 23.466/86). The same attributes used to define the disappeared also reciprocally define the identity of relatives and justify restorative policies: "[the family], the core of our social organization, [...] has been severely attack with the kidnapping and later disappearance of one or more of its members. We must repair the damage caused." ${ }^{34}$ This analysis reveals the consecration of a public rhetoric that excludes any reference to the political identities of the actors involved by privileging family ties instead.

Through these laws, guided by feelings of empathy and compassion, the family was recreated as a new victim. Although State terrorism had been suffered “...to a greater or lesser extent by the entire Argentine people, there were and is another victim atrociously assaulted: the victim's family" (ibid). These families were defined by the moral damage experienced with the disappearance of one of its members, and the situation of economic helplessness in which they were left without the support of the disappeared provider. This appeal to the family is based on a belief shared by the State and by members of human rights associations concerning the positive value of kinship and the place that family is considered to occupy within the nation. Paraphrasing Benedict Anderson (1991), kinship creates an imagined community, but not a fictitious one since its terms are intelligible to all its members.

In the process of giving social existence to the disappeared, the State helped turn those claiming to be relatives into new victims. Through the approval and regulation of this array of laws, the State created and officially recognized a new kind of social category: the "relative of the victim." Families of the victims become a responsibility of the nation, a nation now devoted to protecting them. These laws are effectively acts of institution (Bourdieu 1994) through which the identities of the Argentinean nation were redefined. 
Those who succeeded in being recognized as a target of these policies - and thus included within the nation - were those who received a politically neutral but morally powerful identity: the victims and their families. These devices played a fundamental role in the crystallization and sacralisation of a way of imagining the nation as a family of victims (Vecchioli 2005; Filc 1997).

Over the years, any sign of proximity between human rights associations and the State was condemned as a threat to the purity of such activism and its place of moral significance. Conversely, proximity to these associations cast suspicion on the political impartiality of former presidents Alfonsín and Menem, both of whom faced various attempted coups d'état led by military sectors opposed to the trials for crimes against humanity. Alfonsín was a lawyer and a founder member of a human right association, while Menem had been kept imprisoned throughout the dictatorship. Alfonsin's commitment to human rights ended up in a major civil trial that condemned those responsible for State terrorism. At the beginning of democracy, human rights and partisan activism, 'blood' and 'politics,' were considered antithetical.

Since the arrival of Néstor Kirchner to the presidency in 2003, though, the distance that once characterized the relationship between human rights associations, political parties and the State has become erased. A significant number of recovered grandchildren entered the electoral lists of the Coalition for Victory, aiming to promote the human rights cause. This new combination of legitimate attributes was masterfully expressed by the recovered grandson Pietragalla, who claimed "I am the congressman of the Grandmothers". 35

The very same afternoon that the courts informed Estela that her grandson had appeared, Cristina Kirchner, president at the time, phoned to congratulate her. Asked about this conversation, Estela described it as a "mother-daughter communication" during which both women cried with emotion (Guinzberg 2014). Likewise, the informal reunion in the presidential residence a few days later - described as an intimate meeting - was compared to a snapshot of a family gathering of three generations: the children recovered and the children of the president; the parents and comrades from the 197os generation represented by Cristina and other high-ranking public officials; and the grandmother, Estela. The president herself used her Twitter account to circulate the photo, showing her dinner with Ignacio and Estela at the presidential residence.

Photo 2: Cristina Kirchner, Ignacio Carlotto Montoya and Estela de Carlotto at the presidential residence

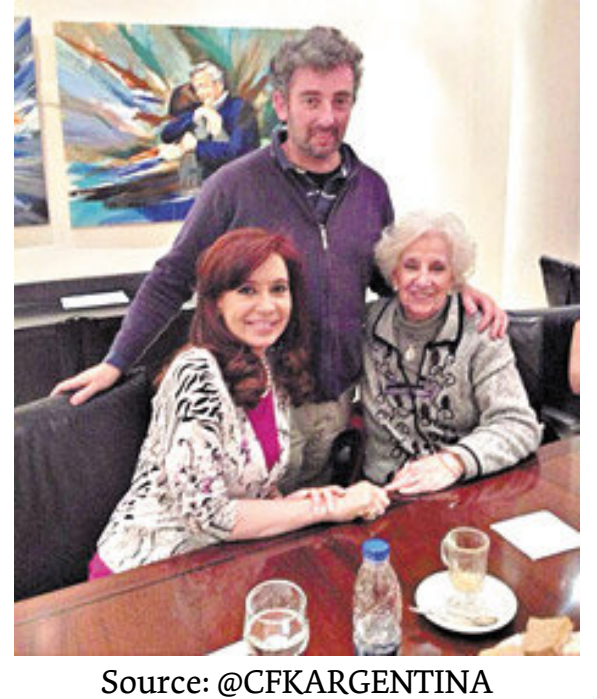

35 "Soy el diputado de las abuelas" Página/12 newspaper. November 20 $\mathrm{o}^{\text {th }}$, 2011. https://www.pagina12.com.ar/diario/elpais/1-181617-2011-11-20.html Accessed on April $5^{\text {th }}, 2017$. It is interesting to contrast this claim with the slogan "human rights for parliament" used at the beginning of democracy by Augusto Conte, a lawyer, leader of a human rights organization (CELS) and father of a disappeared, who entered the national parliament via the electoral list of the Christian Democratic Party (Ferrari 2017). In a previous work, I analysed the implications of the distinction between claiming a particularistic principle as blood and claiming a universalist principle as law (Vecchioli 2013). 
Unlike former presidents Alfonsín or Menem, the Kirchners had no historical roots in the human rights movement or any involvement as political prisoners during the dictatorship. In their place, fictitious kinship relationships were recreated, and blood ties were extended to reach human rights activist. In this new family setup, Cristina is represented as Laura's sister and Estela as the mother of both. The authors of the book The Grandson accentuated their similarities, contributing to the crystallization of this family: "The president has a resemblance to Laura. The hair, the age, the way of speaking...” (Seoane \& Caballero2015: 16). Photos circulated extensively confirming this resemblance.

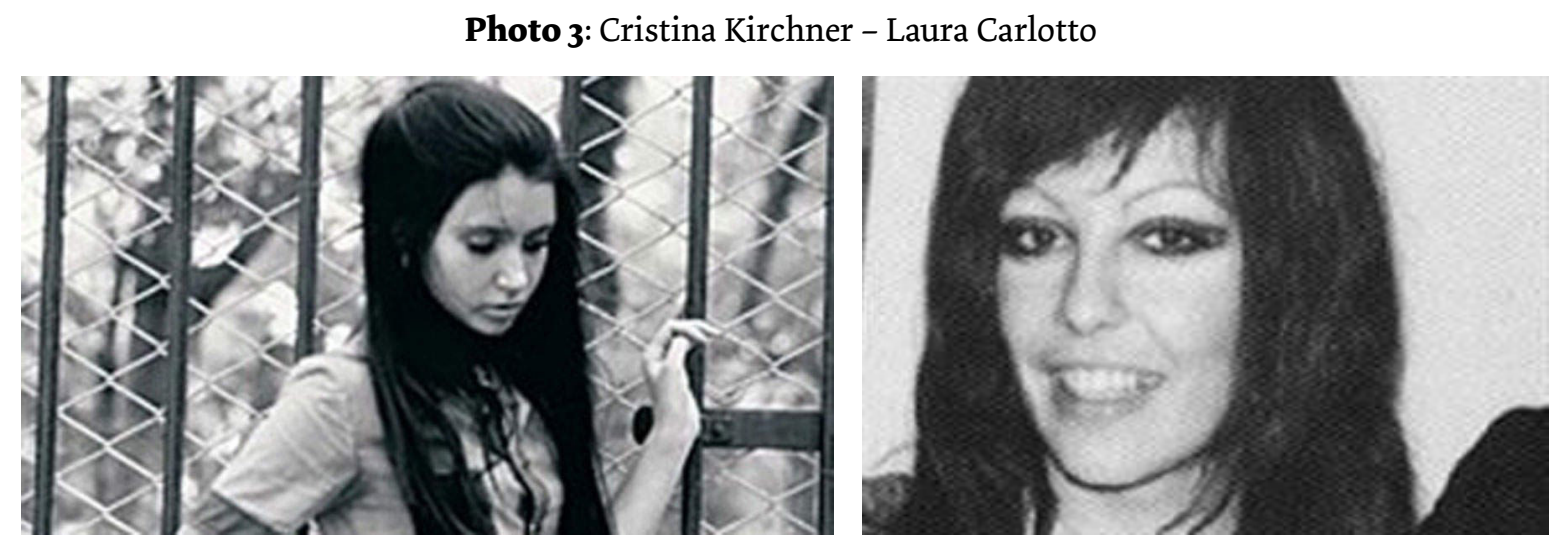

Source: La Nación newspaper

For Estela, the similarities were extended and deepened because Oscar, Ignacio's father, was a Patagonian native like Néstor, while Laura was a native of La Plata like Cristina. They had all lived in La Plata during the 1970 s where they were university students and political activists. A newspaper report added: "A similar history to the presidential couple, who also met each other while both were studying Law at the University of La Plata." ${ }^{36}$

Kinship ties were recreated on the basis of the truth revealed by blood ties and on their life trajectories, presented as identical: a life devoted to and consecrated by - in the cases of deceased former president Néstor Kirchner and the parents of disappeared Ignacio - the commitment to fight for a cause, now recreated as a cause shared by them all. This communion appears further accentuated when we note that all of Estela de Carlotto's sons and daughter were active, in one form or another, in the structure of the Kirchner government: Claudia as a director of the National Commission for the Right to Identity (CONADI), Guido as Human Rights Secretary for the Province of Buenos Aires, and Remo as a national deputy for the Collision for Victory and president of the Human Rights and Guarantees Commission.

The novelty expressed here was not the incorporation of the Carlotto family into the structure of the State. In fact, the central criterion for the recruitment of officials in those State areas responsible for human rights policies has been their status as either victims (former political prisoners, exiles, survivors), relatives of a victim, or their past commitment to the fight for human rights. ${ }^{37}$ The novelty, rather, was the symbolic integration of the Carlottos and Kirchners into the same family as a single moral and political space.

\footnotetext{
36 "Relato de un encuentro íntimo." Página/12 newspaper. September 10, 2014. Available at http://www.pagina12.com.ar/diario/elpais/1-252672-2014-08-10. html My emphasis. Accessed on September 10 $0^{\text {th }}, 2014$.

37 These criteria determined the heads of the human rights agencies at national level from 1983 to 2015: from E. Rabossi, A. Pierni, D. Conti, E. M. Duhalde to M. Fresneda (a recovered grandchild).
} 
This aim in mind, the biographies of the family members were recreated and imagined as convergent. The use of the plural testifies to this belonging to the same family constellation and the work involved in its construction. As Kirchner put it: "It's amazing, isn't it? We were all so nearby yet none of us had ever met." ${ }^{8}$

The recreation of the State as a family of victims began with the first speech made by president Néstor Kirchner to the $58^{\text {th }}$ UN Assembly in 2003, when he addressed the global community through an appeal to primordial ties: "we are the sons and daughters of the Mothers and Grandmothers of the Plaza de Mayo," 39 an expression that foregrounds not only the constructed nature of this relation of maximal proximity with the victims and their families, but also the critical importance that these primordial relations acquired thereafter in the constitution of the State itself. Numerous different occasions make explicit this work of creating and recreating these imaginary bonds: ranging from State rituals involving senior officials or party activists, but also leaders of the associations of the relatives of victims, to the celebrations of Mother's Day in which Cristina published photos of herself in the company of Estela and Hebe de Bonafini, the president of the Mothers of Plaza de Mayo Association.

The use of the family model cannot be seen simply as a discursive strategy employed by each of these two groups to maximize their demands or their potential for political support. My intention is to transcend explanations of social action as based on bare cost-benefit calculations and highlight the ways in which people's actions are informed by moral values. Thus, the appeal to family values and ties in the cases analysed here is based on a belief shared by the State and members of civil society organizations concerning the strength and positive value of kinship and the place occupied by the family in national society. Unlike more black and white viewpoints that judge the human rights movement to have been 'coopted' by Kirchnerism, my analysis proposes that novelty has resided not in the inclusion of activists from human rights organizations in the structure of the State - a process initiated in 1983 - but in the reconversion of grandchildren into professional politicians and in the inclusion of consanguine relationships with victims as part of the very constitution of the State - as revealed in Néstor Kirchner's claim that "we are the sons and daughters of the Mothers of Plaza de Mayo" or by the grandchild's assertion that "I am the congressman of the Grandmothers." State, victims and relatives thus became symbolically integrated within the same moral unit as members of the same family.

These closening ties were not conflict-free. Maria Victoria Moyano's arrest while participating in a union demonstration reveals the existence of frontiers that define who may be considered as a legitimate victim, a grandchild who deserves feelings of compassion. Even though Ignacio and Maria Victoria are classified as 'siblings' within the Children association (Hijos por la Identidad y la Justicia, contra el Olvido y el Silencio HIJOS), María Victoria merited neither the same emotion when she was recovered, nor any feeling of compassion following her arrest in 2014. ${ }^{\circ}$

\footnotetext{
38 "Retrato de un encuentro íntimo." (op.cit.).

39 Kirchner, Néstor "Discurso de N. Kirchner en la ONU" Cristina Fernández de Kirchner September 25 $5^{\text {th }}, 2003$, accessed on March $8^{\text {th }}, 2015$ http://www. cfkargentina.com/discurso-de-nestor-kirchner-en-la-onu-2003/

40 Although the union protest was covered by a few national media sources, attention was focused on the aggressive attitude of the gendarmerie, led by Berni, a prominent national leader of Kirchnerism. During that pre-electoral period, critics focused on Berni in order to show how Cristina Kirchner's government was not fully democratic. Almost no mention was made of Victoria's arrest.
} 


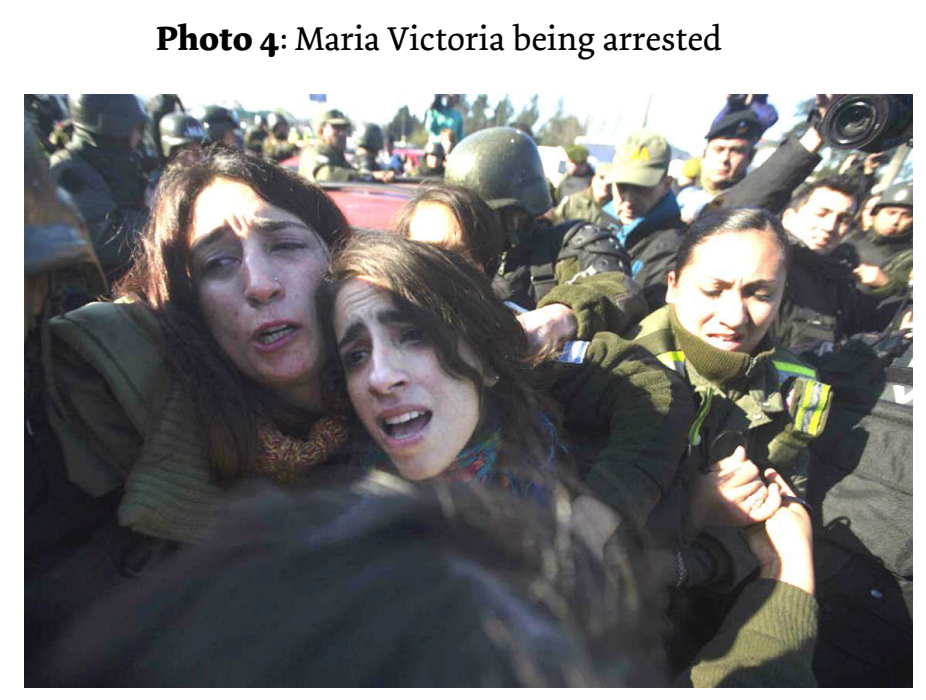

Source: Telam

These two episodes expose the existence of a moral hierarchy that permeates the "blood that circulates through the veins," establishing symbolic distinctions among the children of the disappeared who positively assumed the "truth revealed" by the DNA test. According to Fassin (2011), humanitarian reason provokes a sentimentalization of political relations, albeit only those capable of being represented as worthy in public space. If worthiness is a quality possessed by those figures who demand compassion, the absence of this collective feeling in the case of María Victoria may be rooted, precisely, in the social properties gathered in her biographic profile: on one hand, she has all the attributes currently associated with recovered grandchildren: she is politically active and a member of a human rights association. But at the same time, María Victoria is a member of a rival political party and a member of a human rights organization that defines itself as 'independent' of the State. The Centre of Professionals for Human Rights (CeProDH, 1997) took out legal action against Kirchner's head of the army at the time, César Milani, accused of the crime of genocide for his alleged involvement in the disappearance of persons during the last dictatorship. The association also campaigned for those disappeared under Kirchner's rule, such as Julio López - survivor from a clandestine detention centre and disappeared before providing testimony in one of the more recent trials for crimes against humanity in 2006 - and Luciano Arruga, a teenager who disappeared in 2009 while in police custody, to name just two of various such cases. Reflecting on her position within the political field, María Victoria remarked: "Very often, for the grandchildren who scrap, fight for the workers and defend them, there are only batons and repression." ${ }^{41}$ This was a position radically different from the 'good grandsons' such as Pietragalla or Cabandie, both national congressmen during that period.

As we can discern from these examples, it is not blood that automatically legitimizes the victims, but the way in which blood circulates in people's veins, in accordance with feelings and dispositions controlled by the State and with profiles and trajectories with whom many Argentineans could identify, as expressed by the opposite figures represented by Estela de Carlotto and Hebe de Bonafini. Compassion emerges when a connection exists between the moral status of the human right activists, the attitude assumed by the recovered grandchild towards his or her biological family, and the position occupied by all these actors

41 Moyano, Victoria “Cada nieto que se recupera es un hermano nuestro que aparece." El Intransigente.com. August, 19 ${ }^{\text {th }}, 2014$. Accessed on August $19^{\text {th }}, 2014$ http://www.elintransigente.com/argentina/2014/8/19/ victoria-moyano-cada-nieto-recupera-hermano-nuestro-aparece-261067.html. For a further description based on Moyano's own words, see TVPTS EL CANAL DE LA IZQUIERDA https://www.youtube.com/watch?v=RYX8394udPM, accessed on December 15 ${ }^{\text {th }}$, 2017. On Moyano as a political leader, see TVPTS EL CANAL DE LA IZQUIERDA https://www.youtube.com/watch?v=HnyYoDPrsgo. The documentary "El robo" provides a complete picture of her life: https://www.youtube.com/watch?v=2MzDM_G8WaQ. This film was never released in a commercial movie theatre. 
vis-à-vis the State. Through a sentimentalization of public space, a unique and exclusive case, such as Ignacio's restitution described earlier, is able to garner support among those not directly involved, turning the State and the national community into a single family united by blood ties and mutual empathy. As Alexander has emphasized, "this only happens once in a while, when the [right] symbols are aligned" (Alexander 2002:4).

\section{Final considerations}

In this article I have taken advantage of the recent literature on humanitarianism, specifically its emphasis on the constructed quality of feelings of compassion towards victims in contemporary politics, in order to understand the different moral status of victims of State terrorism in Argentina. I have presented paradigmatic cases as privileged instances that communicate the key role played by blood ties and family values in forming legitimate political representation and the significant place granted to the suffering of the victims in the configuration of the State. These public scenes reveal the way love, kindness, blood, compassion and empathy constitute the fabric of practices and values of humanitarian patterns of government, the setting in motion of a variety of mechanisms of State administration, the intervention of expert knowledge, and the mobilization of humanitarian sentiments.

The State runs and is reproduced by bureaucratic devices but also by affective engagements, by practices that extends kinship and emotions in order to achieve the condition of being a relative of victims. We are faced by a process through which affairs of the State are conceived as though they were family affairs. It is vital to recognize that while the academic literature's emphasis has been on identifying how the State intervenes decisively in the configuration of families and domestic relations, the situations described here show that appeals to the family - and the families of victims in particular, evoking all the values, emotions and sentiments with which they are associated - can become a plausible form of doing politics and, indeed, a means of establishing a hegemonic position within the State's field of power.

From the return to democracy, the State was a crucial actor in the consolidation of consanguinity and filiation as 'natural' principles of adhesion to a collective cause, as revealed in the diverse policies developed to remedy the consequences of human rights violations. These involve a wide array of mechanisms for managing the suffering of the victims, ranging from the creation of the National Genetic Database (1987) and the National Commission for the Right to Identity (Conadi 1992) to the sanctioning of a law that permits DNA to be obtained via court order (26.549/2009), among many other devices that perform a crucial role in cementing this form of imagining the nation as a family. The appeal to the family is based on a belief shared by the State and by those belonging to the human rights associations concerning the positive value of kinship and the place that the family is held to occupy in the nation.

The extraordinary events that followed Ignacio's restitution express the leading role played by the families of victims of State terrorism in Argentine's political space, the powerful confluence between the setting in motion of a variety of devices of State administration, the intervention of expert knowledge (geneticists), and a collective mobilization sustained over a forty-year period. The long-term cultivation of sensibilities that began in 1983 and intensified after 2003, eventually exploded with the recovery of Ignacio, a national event that unleashed expressions of fervour and sympathies. All these social forces contributed to institute, consecrate and simultaneously naturalize this singular form of building a collective cause, narrated and enacted in the public space via the language of kinship and family values. The cumulative work of inculcating the appropriate affective dispositions vis-à-vis the families of victims and the place that suffering should occupy in the public agenda erupted following the discovery of Estela's grandson. 
The appearance of Ignacio consecrates the legitimacy of these ties, as well as the legitimacy of a State that recognizes their centrality, especially in the case of the disappeared grandchildren who, given their status as absolute victims, are able to remain above any kind of public controversy. The family photo at the presidential residence reflects the successful incorporation of the demands of the human rights movement as State policy and how the State is conceived as an extended family that unites the Kirchners, Carlottos, Grandmothers, Mothers and Children on the basis of ties that are fictitious yet still founded strategically on the truth revealed by blood ties and on the near identical life trajectories of all the political actors involved.

Grandson 114's appearance was experienced in public space as a heroic feat through which the consecrated image of the family magically materialized in front of the eyes of all the ritual's participants and spectators. The case shows how feelings of pain, compassion, empathy and redemption, along with the appeal to a 'blood community,' as traditional principles of adhesion not only remain active within the framework of modern States and the global community, they have also become a key site of contemporary politics (Fassin 2011).

As Stoler reminds us, the language of feelings is not a way of 'masking' the true, dispassionate and malefic interests of the State. It is a substantial part of politics, a form through which the State presents itself as a moral space. It involves sentiments and moral values that lend motivation and meaning to the bureaucratic structures of the Nation State and the transnational community. They become instituted as forms of governance by reordering the relations within the State and the global community (Stoler 2007:18). Through these family metaphors, along with the values associated with them, our representations of political life appear inscribed in our bodies as noble emotions and feelings.

This recourse to feelings to express political ties is truly effective, however, only when victims are constructed through the appropriate symbols - that is, as legitimate victims, deserving compassion - and when these feelings and values are in turn mobilized through agents possessing the social skills necessary to do so. This is also recognizable in the context of the claims made by relatives of the victims of police repression in the suburban peripheries, who are stigmatized as mothers of criminals or drug dealers and considered to be illegitimate victims (Bermudez 2017; Vianna \& Farias 2011). Or again, in the intriguing paths taken by the political movement seeking legal reparation for the human rights violations perpetrated by the Brazilian government against children of the compulsorily institutionalized patients of Hansen's disease, who were separately involuntarily and raised by other families or the State. Starting out from a stigmatized condition, they attained public recognition of the traumatic experience of forced separation from their mother and/or father after forty years of activism (Fonseca 2015).

As shown in the different scenes described in this text, the worthiness and skills required to become an object of feelings of compassion and empathy are unevenly distributed. The public indifference towards María Victoria Moyano's arrest sheds light on the effectiveness of the family-State in imposing the appropriate feelings and expectations and its capacity to establish moral hierarchies and boundaries among the victims' families. When included in political analyses, affect and emotion are often reduced to an instrumental mechanism of governmental power or treated as epiphenomenal to the real business of rule. In contrast, this analysis has explored the State as the object of emotional investment by considering how emotion is implicated in a variety of everyday and exceptional encounters between citizens and state agents. The politicization of the affects of particular spaces - that is, the act of binding these intensities to political symbols and discourses - is one important way in which the State acquires a tangible, affective and spatial reality, as well as becoming invested by the moral values associated with kinship and victimhood. 
Received: September 30, 2017

Approved: February 22, 2018

Translator: David Rodgers

\section{References}

ABDO FEREZ, María Cecilia. 2014. "La vuelta de Ignacio a Guido." Página/12. August 12 ${ }^{\text {th }}$, 2014. https://www. pagina12.com.ar/diario/elpais/1-252801-2014-08-12.html

ALEXANDER, Jeffrey. 2002. "On the social construction of moral universals. The 'Holocaust' from War Crime to Trauma Drama." European Journal of Social Theory, 5(1): 5-85.

ANDERSON, Benedict. 1991 Imagined Communities. Reflections on the origins and Spread of Nationalism. London: Verso.

ARENES, Carolina; PIKIELNY, Astrid. 2016. Hijos de los 70. Historias de la Generación que heredó la tragedia argentina. Buenos Aires: Ed. Sudamericana.

BERMUDEZ, Natalia. 2017. "Sin Facundo no hay Nunca Más. Trayectorias, contiendas morales y opacidades en la producción social de una víctima 'no inocente' en Córdoba (Argentina).” Papeles del CEIC. Spain. September, n. 2, pp. 1-26. Mimeo.

BOURDIEU, Pierre. 1994. "L'esprit de famille". In : Raisons Pratiques sur la Théorie de L'action. Paris: Editions du Seuil. pp. 135-145. . 2001. "Los ritos de institución”. In: Qué significa hablar. Madrid: Ed. Akal. Pp. 78-86.

BUBLIK, Marcela. 2013. Abuela. La historia de Rosa Roisinblit, una abuela de Plaza de Mayo. Buenos Aires. Ed. La Marca Editora.

CALVEIRO, Pilar. 2008. Poder y Desaparición: los campos de concentración en la Argentina. Buenos Aires: Ed. Colihue..

CAPPIELLO, Hernán. 2014. “Una conferencia cargada de recuerdos y emoción” La Nación August 6th, 2014. Available at : http://www.lanacion.com.ar/1716128-una-conferencia-de-prensa-cargada-de-recuerdos-yemocion

CATELA, Ludmila da Silva. 2001. No Habrá Flores en la Tumba del Pasado. La Experiencia de Reconstrucción del Mundo de los Familiares de Desaparecidos. La Plata: Ediciones Al Margen.

CRENZEL, Emilio 2014. “Tan lejos, tan cerca.” Página/12. August 28 $8^{\text {th }}$, 2014. . 2011. "Between the voices of the state and the human rights movement: Never Again and the memories of the disappeared in Argentina." Journal of Social History, 44: 1063-1076.

DAS, Veena. 1996 Critical Events. An anthropological perspective on Contemporary India. New Delhi: Oxford University Press.

DURKHEIM, Emile. 2012. Las formas Elementales de la Vida Religiosa. El sistema totémico en Australia. Mexico: FCE.

FASSIN, Diddier. 2011. La Raison Humanitaire. Une histoire morale du temps présent. Paris: Gallimard/ Seuil. FERRARI, Marcela. 2017. "La Democracia Cristiana Argentina durante la dictadura cívico-militar y la transición temprana." Historia, 50(1): 49-77, January-June. Available at http://revistahistoria.uc.cl/index. php/rhis/article/viewFile/124/119 Accessed on: August, $15^{\text {th }}, 2017$.

FILC, Judith. 1997. Entre el parentesco y la política. Buenos Aires: Ed. Biblos.

FONSECA, Claudia. 2015. “Time, DNA and Documents in family reckonings”. Vibrant, 12(1): pp. 75-108. FOLCO, Javier. 2015. Estela. La biografía de Estela de Carlotto. Buenos Aires: Editorial Marea. 
GATTI, Gabriel. 2011. "Imposing Identity against social catastrophes. The strategies of (re) generation of meaning of the Abuelas de Plaza de Mayo." Bulletin of Latin American Research, o(o): 1-16.

GRINZBERG, Victoria. 2014 "Al final, Guido buscó a Estela." Página/12, August 6 6 $^{\text {th }} 2014$ http:/|www.pagina12. com.ar/diario/elpais/1-252358-2014-08-06.html

JENKINS, Janis. 1991 "The State construction of affect: political ethos and mental health among Salvadoran refugees." Culture, Medicine Psychiatry, 15: 139-165.

HIRSCHMAN, Albert. 1997. The passions and the interests: political arguments for capitalism before its triumph. Princeton: NJ. Princeton University Press.

LASZCZKOWSKIi, Mateus; REEVES, Madeleine. 2015. "Affective States-Entanglements, Suspensions, Suspicions." Social Analysis, 59(4): 1-14.

LENOIR, Rémi. 2003 Généalogie de la morale familiale. Paris : Seuil.

LUDUEÑA, María Eugenia. 2014 "Ignacio Guido Carlotto: la música que sobrevivió a los campos de concentración." Infojus Noticias. August $9^{\text {th }}$, 2014. http:/|www.infojusnoticias.gov.ar/opinion/ignacioguido-carlotto-la-musica-que-sobrevivio-a-los-campos-de-concentracion-127.html

MELLIBOVSKY, Matilde. 199o. Círculo de amor sobre la muerte. Buenos Aires: Ed. del Pensamiento Nacional. REGUEIRO, Sabina. 2010. Apropiación de niños durante la última dictadura militar argentina. Tramas burocráticoadministrativas y estrategias jurídico-políticas en la construcción de parentescos. $\mathrm{PhD}$ thesis, Facultad de Filosofía y Letras, UBA.

RORTY, Richard. 1989. Contingency, Irony and Solidarity. Cambridge: Cambridge University Press.

SARTI, Cynthia. 2011. "A vítima como figura contemporânea." Cadernos CRH, 24(61): 51-61.

SEOANE, María; CABALLERO, Roberto. 2015. El Nieto. La trágica y luminosa historia de Ignacio ‘Guido’ Montoya Carlotto robado por la dictadura y recuperado por Abuelas de Plaza de Mayo. Buenos Aires: Ed. Sudamericana.

STOLER, Ann Laura. 2007. “Affective States.” In: David Nugent and Joan Vincent (eds.), A Companion to the Anthropology of Politics. Oxford: Blackwell. pp. 4-21.

SUTTON, Barbara. 2015 "Collective Memory and Human Rights Language." Latin American Perspectives, 202(42/3): 73-91.

TAITÁN, Diego. 2014, "La nobleza de una emoción colectiva”. Revista Anfibia, Agosto. Universidad Nacional de San Martín. http://revistaanfibia.com/ensayo/la-nobleza-de-una-emocion-colectiva/

TEITEL, Ruti. 2002 “Transitional Justice in a new era." Fordham International Law Journal, 26(4): pp. 893-906. VECCHIOLI, Virginia. 2013. "Por una aproximación política a la justicia transicional: creación, circulación y usos de la categoría víctima en los dispositivos de justicia transicional en la Argentina." Revista Jurídicas, 10(2): pp.9-23. Centro de Investigaciones Socio-Jurídicas de la Universidad de Caldas, Colombia. . 2005. "La nación como familia. Metáforas políticas en el movimiento por los derechos humanos en la Argentina." In: S. Frederic and G. Soprano (eds.), Cultura y Política en Etnografías sobre la Argentina. Buenos Aires: Ed. UNQ/Prometeo. Pp. 241-269.

VIANNA, A.; FARIAS, J. 2011, “A guerra das mães: dor e política em situaç̃̃es de violência institucional." Cadernos Pagu, 37: 79-116.

Virginia Vecchioli

Professor, Social Sciences Department.

Federal University of Santa Maria - UFSM, Santa Maria, RS, Brazil

https://orcid.org/o00o-0002-0260-5287

E-mail: vvecchioli@gmail.com 